\title{
PENGARUH KUALITAS PELAYANAN, PEMASARAN RELASIONAL DANKEPUASAN NASABAH TERHADAP LOYALITAS NASABAH PT BANK BRI CABANG BANDAR LAMPUNG
}

\author{
Tria Arvina Tiara ${ }^{1}$ Dora Rinova ${ }^{2}$ \\ ${ }^{1}$ Fakultas Ilmu Sosial dan Ilmu Politik, Universitas Bandar Lampung \\ Jl. Zainal Abidin Pagar Alam No.26, Labuhan Ratu, Kedaton, 35142, Bandar Lampung, \\ Indonesia \\ E-mail: \\ triaarfna@gmail.com \\ dora@ubl.ac.id
}

\begin{abstract}
ABSTRAK
Penerapan hubungan pemasaran yang dilakukan PT Bank BRI Cabang Bandar Lampung tidak sepenuhnya diterima oleh semua pelanggan, karena untuk mendapatkan pelayanan khusus atau perhatian dalam penerapan hubungan pemasaran diberlakukan syarat dan ketentuan. Penelitian ini dilakukan dengan tujuan mengetahui mengetahui pengaruh pemasaran relasional dan kepuasan pelanggan terhadap loyalitas nasabah PT Bank BRI Cabang Bandar Lampung. Penelitian ini termasuk ke dalam penelitian kuantitatif. Populasi pada penelitian ini adalah populasi dalam penelitian ini adalah nasabah PT Bank BRI Cabang Bandar Lampung selama 3 bulan sebanyak 60 orang dan jumlah sampel sebanyak 60 orang. Analisis dalam penelitian ini menggunakan analisis regresi linier berganda. Hasil penelitian menunjukkan $\mathrm{F}_{\text {hitung }}=43,632>\mathrm{F}_{\text {tabel }}=3,16$ dengan signifikansi sebsar 0,000 yang berarti bahwa ada pengaruh kualitas pelayanan, pemasaran relasional dan kepuasan pelanggan terhadap loyalitas nasabah PT Bank BRI Cabang Bandar Lampung.
\end{abstract}

Kata Kunci: Kualitas Pelayanan, Pemasaran Relasional, Kepuasan Pelanggan, Loyalitas Nasabah

\section{PENDAHULUAN}

Pada saat ini persaingan antar perusahaan semakin ketat, persaingan tersebut membuat perusahaan harus merancang strategi pemasaran yang inovatif untuk mendapatkan simpati pelanggan. Pemikiran strategis melalui kegiatan pemasaran yang tepat sangat dibutuhkan dalam upaya menonjolkan kehadiran produk atau jasa perusahaan. Perusahaan harus dapat memberikan pelayanan yang cepat dan tepat serta dapat mempermudah mobilitas pelanggan sehingga pelanggan mengambil keputusan untuk menjadi pelanggan perusahaan tersebut. Strategi yang dilakukan oleh perusahaan selalu bertujuan agar jumlah pelanggan dapat terus meningkat. Peningkatan jumlah pelanggan tersebut, merupakan bukti bahwa pelanggan tersebut puas dengan produk-jasa yang diberikan oleh pihak perusahaan. Komitmen terhadap kepuasan pelanggan inilah yang mendorong perusahaan yang bergerak dalam dunia perusahaan perlu bekerja keras dalam memperbaiki dan meningkatkan kualitas produk dan pelayanan terhadap pelanggan, Chandra dan Danny (2010).

Fungsi semua perusahaan hampir sama, perbedaannya terletak pada pelayanan, fasilitas, informasi teknologi dan lain sebagainya yang ditawarkan kepada masyarakat. Dari berbagai bentuk produk-jasa yang ditawarkan pihak perusahaan kepada pelanggan, yang menjadi closing point kepuasan pelanggan adalah ketika produk-jasa yang diberikan melebihi kebutuhan dan harapan pelanggan. Jika pelanggan kecewa terhadap pelayanan yang diberikan oleh pihak perusahaan, besar kemungkinan pelanggan akan pindah ke perusahaan lain, Chandra dan Danny (2010). 
Kepuasan pelanggan ditentukan oleh kualitas barang atau jasa yang dikehendaki pelanggan, sehingga jaminan kualitas menjadi prioritas utama bagi setiap perusahaan sebagai tolak ukur keunggulan daya saing perusahaan tersebut. Kualitas pelayanan dalam perusahaan jasa merupakan hal yang sangat penting dari sudut pandang konsumen. Konsumen tidak hanya menilai dari hasil jasa, tetapi juga dari proses penyampaian jasa tersebut. Pelanggan yang merasa puas akan mempunyai loyalitas yang tinggi pada produk atau jasa suatu perusahaan, Gronross (2008).

Pelanggan diibaratkan seorang raja yang harus dilayani, namun hal ini bukan berarti menyerahkan segala-galanya kepada pelanggan. Usaha memuaskan kebutuhan pelanggan harus dilakukan secara menguntungkan atau bersifat "win-win situation" yaitu dimana kedua belah pihak merasa senang atau tidak ada yang dirugikan. Kepuasan pelanggan merupakan suatu hal yang sangat berharga demi mempertahankan keberadaan pelanggannya tersebut untuk tetap berjalannya suatu bisnis atau usaha, Chandra dan Danny (2010).

Kotler (2010) berpendapat bahwa perusahaan-perusahaan yang bergerak dalam bidang perusahaan merupakan bisnis jasa yang berdasarkan pada azas kepercayaan sehingga masalah kualitas layanan menjadi faktor yang sangat menentukan dalam keberhasilan usaha. Kualitas layanan merupakan suatu bentuk penilaian konsumen terhadap tingkat layanan yang diterima (perceived service) dengan tingkat layanan yang diharapkan (expected service). Agar dapat bersaing, bertahan hidup, dan berkembang, maka perusahaan perusahaan dituntut untuk mampu memberikan pelayanan berkualitas yang dapat memenuhi kebutuhan dan keinginan pelanggan.

Harapan pelanggan bersifat dinamis dan berkembang dari waktu ke waktu. Perkembangan ini salah satunya dilatar belakangi oleh kemajuan Informasi dan Teknologi (IT), karena kemajuan IT diikuti oleh bertambahnya fitur-fitur produk perusahaan yang memudahkan pelanggan bertransaksi. PT Bank BRI Cabang Bandar Lampung menerapkan berbagai strategi untuk mempertahankan pelanggannya dengan meningkatkan kualitas layanan dan melakukan program personal tidak menggunakan data base yang semestinya, Assauri (2008).

Penerapan hubungan pemasaran yang dilakukan PT Bank BRI Cabang Bandar Lampung tidak sepenuhnya diterima oleh semua pelanggan, karena untuk mendapatkan pelayanan khusus atau perhatian dalam penerapan hubungan pemasaran diberlakukan syarat dan ketentuan. PT Bank BRI Cabang Bandar Lampung memiliki jumlah pelanggan yang paling besar namun tidak semua pelanggan PT Bank BRI Cabang Bandar Lampung aktif dalam melakukan transaksi pada produk PT Bank BRI didasarkan pada kerjasama yang dilakukan pihak perusahaan.

Bagi pelanggan ada yang berpotensi untuk memberikan informasi kepada calon pelanggan tentang pelayanan yang diterima dan dialaminya selama bertransaksi. Penurunan ini menunjukkan pelanggan tidak lagi mudah dipengaruhi dengan promosi atau janji di awal transaksi. Dalam hubungan pemasaran pelanggan menjadi prioritas utama. Pelanggan merupakan aset yang berharga karena kontribusinya yang tinggi terhadap penjualan dan profit dengan menjadi duta yang baik bagi perusahaan dalam mengakuisisi pelanggan baru melalui pengalaman masa lalu, keinginan pelanggan, mulut ke mulut (word of mouth) yang disebarkan baik kekalangan teman-teman, rekan sekerja atau bahkan keluarga.

Dalam menyusun strategi pemasaran untuk dapat mempertahankan pelanggan. Kepuasan pelanggan merupakan komponen utama dalam strategi pemasaran dan dalam strategi 
persaingan. Oleh sebab itu, banyak perusahaan khususnya perusahaan dalam melaksanakan strategi lebih menekankan pada harapan pelanggan diyakini mempunyai peranan yang besar dalam menentukan kualitas jasa dan menjalin kerjasama dengan pelanggan. Faktor-faktor harapan pelanggan yang terdiri dari: Pengalaman masa lalu meliputi hal-hal yang telah dipelajari atau diketahui pelanggan dari yang pernah diterimanya pada masa sebelumnya. Harapan pelanggan ini dari waktu ke waktu berkembang, seiring dengan semakin banyaknya informasi (non experimental information) yang diterima pelanggan serta semakin bertambahnya pengalaman pelanggan. Mulut ke mulut word of mouth merupakan pernyataan (secara personal atau non personal) yang disampaikan oleh orang lain selain organisasi kepada pelanggan. Mulut ke mulut word of mouth ini biasanya cepat diterima oleh pelanggan. Disamping itu mulut ke mulut word of mouth ini cepat diterima sebagai referensi karena pelanggan biasanya sulit mengevaluasi jasa yang belum dibelinya atau belum dirasakannya sendiri.

Setiap perusahaan dituntut untuk menggunakan berbagai cara dalam menarik minat masyarakat. Perusahaan sebagai lembaga keuangan yang usaha utamanya memberikan jasa penyimpanan dan menyalurkannya kembali dalam berbagai alternatif pinjaman kepada masyarakat juga perlu memfokuskan pada kinerja pelayanan untuk memuaskan pelanggannya. Mencermati hal tersebut maka PT Bank BRI Cabang Bandar Lampung memandang fenomena ini sebagai peluang bisnis yang besar. Sebagai implementasi dari visi, misi, dan sasaran jangka panjang, manajemen PT Bank BRI Cabang Bandar Lampung telah berkomitmen untuk memasuki persaingan bisnis.

Tabel 1. Pertumbuhan pelanggan PT Bank BRI Cabang Bandar Lampung (dalam persentase)

\begin{tabular}{|c|cc|cc|cc|}
\hline Tahun & \multicolumn{3}{|c|}{2017} & & 2018 & \\
2019 \\
\hline Tingkat Pertumbuhan & $(\%)$ & 20,3 & $(\%)$ & 49,8 & $(\%)$ & 29,9 \\
\hline
\end{tabular}

\section{Sumber: PT Bank BRI Cabang Bandar Lampung (2019)}

Periode 2017 sampai 2018 pertumbuhan pelanggan PT Bank BRI Cabang Bandar Lampung mengalami peningkatan. Sedangkan periode 2018 sampai 2019 tingkat pertumbuhan pelanggan PT Bank BRI Cabang Bandar Lampung mengalami penurunan. Dari tabel di atas pertumbuhan pelanggan PT Bank BRI Cabang Bandar Lampung mengalami kenaikan dan penurunan yang tidak stabil.

Pemasaran merupakan salah satu kegiatan pokok yang dilakukan oleh perusahaan untuk mempertahankan kelangsungan hidupnya, tetapi dalam pemasaran modern seperti ini paragdima pemasaran telah bergeser, tidak hanya menciptakan transaksi untuk mencapai keberhasilan pemasaran tetapi perusahaan juga harus menjalin hubungan dengan pelanggan dalam waktu yang panjang. Paragdima tersebut disebut relationship marketing dasar pemikiran dalam praktek pemasaran ini adalah, membina hubungan yang lebih dekat dengan menciptakan komunikasi dua arah dengan mengelola suatu hubungan yang saling menguntungkan antara pelanggan dan perusahaan, Chan S (2008).

Hasil pra survey pada 30 orang pelanggan PT Bank BRI Cabang Bandar Lampung diperoleh data kualitas layanan yang terdiri dari Tangible, Emphaty, Reliability, Responsiveness dan Assurance dengan nilai rata-rata cukup baik di mata pelanggan, seperti yang dijelaskan pada Tabel 2 berikut: 
Tabel 2. Nilai Kepuasan Pelanggan Terhadap PT Bank BRI Cabang Bandar Lampung

\begin{tabular}{|c|l|c|l|}
\hline No & \multicolumn{1}{|c|}{ Kualitas layanan } & $\begin{array}{c}\text { Nilai } \\
\text { Kepuasan }\end{array}$ & \multicolumn{1}{|c|}{ Keterangan } \\
\hline 1 & Berwujud (Tangible) & 7,5 & Baik \\
\hline 2 & Empati (Emphaty) & 7,8 & Baik \\
\hline 3 & Keandalan (Reliability) & 8,0 & Sangat baik \\
\hline 4 & Daya Tanggap (Responsiveness) & 7,9 & Baik \\
\hline 5 & Kepastian atau jaminan (Assurance) & 8,0 & Sangat baik \\
\hline
\end{tabular}

Sumber: PT Bank BRI Cabang Bandar Lampung (2020)

Adapun strategi pemasaran relasional yang dilakukan oleh PT Bank BRI Cabang Bandar Lampung tidak terlepas dari 3 (tiga) tingkatan yang berpengaruh terhadap kepuasan pelanggan, yaitu: financial benefit, social benefit, dan structural ties. Financial benefit adalah pemberian manfaat keuangan dan ekonomis berupa biaya yang dikeluarkan oleh pelanggan. Social Benefit adalah peningkatan hubungan dengan mempelajari kebutuhan dan keinginan pelanggan, bahkan memberikan sesuatu yang sifatnya pribadi. Structural ties adalah ikatan struktural dengan membangun hubungan yang lebih kuat dengan pelanggan, mengarah pada penghargaan dan pengertian yang tinggi yang diberikan perusahaan pada pelanggannya. Ketiga tingkatan tersebut mempunyai pengaruh dalam menciptakan kepuasan pelanggan PT Bank BRI Cabang Bandar Lampung.

\section{TINJAUAN PUSTAKA}

\section{METODOLOGI}

\section{HASIL DAN PEMBAHASAN}

Berdasarkan hasil penelitian dan pengolahan data maka diperoleh data analisis regresi linier berganda sebagai berikut:

Tabel 4.3

Analisis Regresi Berganda

Coefficients $^{\mathrm{a}}$

\begin{tabular}{|c|c|c|c|c|c|c|}
\hline \multirow[b]{2}{*}{ Model } & & \multicolumn{2}{|c|}{ Unstandardized Coefficients } & $\begin{array}{l}\text { Standardized } \\
\text { Coefficients }\end{array}$ & \multirow[b]{2}{*}{$\mathrm{t}$} & \multirow[b]{2}{*}{ Sig. } \\
\hline & & $\mathrm{B}$ & Std. Error & Beta & & \\
\hline 1 & (Constant) & 3,883 & 2,201 & & 10,764 & 030 \\
\hline & $\begin{array}{l}\text { Kualitas_pelayanan } \\
\text { Pemasaran_relasional } \\
\text { Kepuasan_pelanggan }\end{array}$ & $\begin{array}{l}, 715 \\
, 802 \\
, 229\end{array}$ & $\begin{array}{l}, 041 \\
, 086 \\
, 189\end{array}$ & $\begin{array}{l}, 641 \\
, 777 \\
, 010\end{array}$ & $\begin{array}{l}6,215 \\
9,324 \\
4,121\end{array}$ & $\begin{array}{l}, 007 \\
, 000 \\
, 024\end{array}$ \\
\hline
\end{tabular}

a. Dependent Variable: Loyalitas_nasabah

Sumber: Data diolah pada tahun 2021

Berdasarkan tabel 4.3 di atas, kemudian dimasukkan dalam persamaan:

$\mathrm{Y}=3,883+0,715 \mathrm{X}_{1}+0,802 \mathrm{X}_{2}+0,229 \mathrm{X}_{3}+0,05$

Hasil persamaan tersebut menunjukkan bahwa kualitas pelayanan, pemasaran relasional dan kepuasan pelanggan berpengaruh secara positif dan searah terhadap loyalitas nasabah

1) Konstanta sebesar 3,883 yang berarti bahwa loyalitas nasabah mempunyai nilai sebesar 3,883 sebelum dipengaruhi oleh kualitas pelayanan, pemasaran relasional dan kepuasan pelanggan. 
2) Setiap terjadi peningkatan nilai pada variabel kualitas pelayanan sebesar satu satuan maka loyalitas nasabah akan meningkat 0,715 satuan.

3) Setiap terjadi peningkatan nilai pada variabel pemasaran relasional sebesar satu satuan maka loyalitas nasabah akan meningkat 0,877 satuan.

4) Setiap terjadi peningkatan nilai pada variabel kepuasan pelanggan sebesar satu satuan, maka loyalitas nasabah akan meningkat 0,592 satuan.

Berdasarkan keterangan di atas dapat ditarik kesimpulan bahwa nilai koefisien regresi pemasaran relasional lebih besar dari kualitas pelayanan dan kepuasan pelanggan terhadap loyalitas nasabah PT Bank BRI Cabang Bandar Lampung.

Koefisien determinasi bertujuan untuk mengukur seberapa jauh kemampuan model dalam menerangkan variasi variabel dependen. Nilai koefisien determinasi adalah $0<\mathrm{R}^{2}<1$. Koefisien determinasi yang mendekati satu berarti variabel-variabel independen memberikan hampir semua informasi yang dibutuhkan untuk memprediksi variabel dependen. Penggunaan $R$ square adalah bias terhadap jumlah variabel independen yang dimasukkan ke dalam model. Setiap tambahan variabel independen ke dalam model, maka $R$ square pasti meningkat tidak peduli apakah variabel independen tersebut berpengaruh secara signifikan atau tidak. Tidak seperti $R$ square, nilai adjusted $R$ square dapat naik atau turun apabila terdapat tambahan variabel independen ke dalam model.

\section{Tabel 4.4}

Koefisien Determinasi Pengaruh Kualitas pelayanan, pemasaran relasional dan kepuasan pelanggan Terhadap Loyalitas nasabah

\begin{tabular}{|l|r|r|r|r|}
\hline Model & $\mathrm{R}$ & $\mathrm{R}$ Square & Adjusted R Square & $\begin{array}{c}\text { Std. Error of the } \\
\text { Estimate }\end{array}$ \\
\hline 1 &, $778^{\mathrm{a}}$ &, 605 &, 591 & 1,93532 \\
\hline
\end{tabular}

a. Predictors: (Constant), Kualitas_pelayanan, Kepuasan_pelanggan, Pemasaran_relasional Sumber: Data diolah pada tahun 2021

Berdasarkan tabel 4.4 diketahui bahwa nilai $\mathrm{R}^{2}=0,605 \times 100 \%=60,5 \%$ yang artinya besarnya pengaruh pengaruh kualitas pelayanan, pemasaran relasional dan kepuasan pelanggan terhadap loyalitas nasabah PT Bank BRI Cabang Bandar Lampung adalah sebesar $60,5 \%$ sedangkan selebihnya dipengaruhi oleh faktor lain yang tidak dikaji dalam penelitian ini.

Uji $\mathrm{F}$ bertujuan untuk menunjukkan apakah semua variabel independen yang dimasukkan ke dalam model secara simultan atau bersama-sama mempunyai pengaruh terhadap variabel dependen.

a. Membuat hipotesis untuk kasus pengujian F-test di atas, yaitu:

Ho: Tidak ada pengaruh signifikan dari variabel independen yaitu kualitas pelayanan $\left(\mathrm{X}_{1}\right)$, pemasaran relasional $\left(\mathrm{X}_{2}\right)$ dan kepuasan pelanggan $\left(\mathrm{X}_{3}\right)$ secara simultan terhadap variabel dependen yaitu loyalitas nasabah $(\mathrm{Y})$.

Ha: Ada pengaruh signifikan dari variabel independen yaitu kualitas pelayanan $\left(\mathrm{X}_{1}\right)$, pemasaran relasional $\left(\mathrm{X}_{2}\right)$ dan kepuasan pelanggan $\left(\mathrm{X}_{3}\right)$ secara simultan terhadap variabel dependen yaitu loyalitas nasabah $(\mathrm{Y})$.

b. Menentukan $\mathrm{F}$ tabel dan $\mathrm{F}$ hitung dengan tingkat kepercayaan sebesar $95 \%$ atau taraf signifikansi sebesar 5\%, maka:

1) Jika $\mathrm{F}$ hitung $>\mathrm{F}$ tabel, maka $\mathrm{H} 0$ ditolak, berarti masing-masing variabel bebas secara bersama-sama mempunyai pengaruh yang signifikan terhadap variabel terikat. 
2) Jika $\mathrm{F}$ hitung $<\mathrm{F}$ tabel, maka $\mathrm{H0}$ diterima, berarti masing-masing variabel bebas secara bersama-sama tidak mempunyai pengaruh yang signifikan terhadap variabel terikat.

Tabel 4.5

Uji F

ANOVA $^{\mathrm{b}}$

\begin{tabular}{|ll|r|r|r|r|r|}
\hline Model & & Sum of Squares & \multicolumn{1}{|c|}{ df } & Mean Square & F & Sig. \\
\hline 1 & Regression & 326,842 & 2 & 163,421 & 43,632 &, $000^{\mathrm{a}}$ \\
& Residual & 213,492 & 57 & 3,745 & & \\
& Total & 540,333 & 59 & & & \\
\hline
\end{tabular}

a. Predictors: (Constant), Kualitas_pelayanan, Kepuasan_pelanggan, Pemasaran_relasional

b. Dependent Variable: Loyalitas_nasabah

Sumber: Data diolah pada tahun 2021

Berdasarkan hasil uji $\mathrm{F}$ di atas, diperoleh $\mathrm{F}_{\text {hitung }}=43,632>\mathrm{F}_{\text {tabel }}=3,16$ dengan signifikansi sebsar 0,000 yang berarti bahwa ada pengaruh kualitas pelayanan, pemasaran relasional dan kepuasan pelanggan terhadap loyalitas nasabah PT Bank BRI Cabang Bandar Lampung.

Uji t digunakan untuk menunjukkan apakah suatu variabel independen secara individual mempengaruhi variabel dependen (Sugiyono, 2011). Hipotesis yang dipakai adalah:

$\mathrm{H} 0: \mathrm{bi}=0$, artinya suatu variabel independen tidak berpengaruh terhadap variabel dependen.

$\mathrm{Ha}$ : bi>0, artinya suatu variabel independen berpengaruh positif terhadap variabel dependen.

Kriteria pengujian dengan tingkat signifikansi $(\alpha)=0,05$ ditentukan sebagai berikut:

Apabila $t_{\text {hitung }}>t_{\text {tabel }}$, maka $\mathrm{HO}$ ditolak dan Ha diterima.

Apabila $\mathrm{t}_{\text {hitung }}<\mathrm{t}_{\text {tabel }}$, maka $\mathrm{H} 0$ diterima dan Ha ditolak.

Berdasarkan hasil penelitian dan pengolahan data maka diperoleh:

\section{Tabel 4.6}

Uji t

Coefficients $^{\mathrm{a}}$

\begin{tabular}{|c|c|c|c|c|c|c|}
\hline \multirow[b]{2}{*}{ Model } & & \multicolumn{2}{|c|}{ Unstandardized Coefficients } & \multirow{2}{*}{$\begin{array}{l}\text { Standardized } \\
\text { Coefficients } \\
\text { Beta }\end{array}$} & \multirow[b]{2}{*}{$t$} & \multirow[b]{2}{*}{ Sig. } \\
\hline & & $\mathrm{B}$ & Std. Error & & & \\
\hline 1 & (Constant) & 3,883 & 2,201 & & 10,764 &, 030 \\
\hline & $\begin{array}{l}\text { Kualitas_pelayanan } \\
\text { Pemasaran_relasional } \\
\text { Kepuasan_pelanggan }\end{array}$ & $\begin{array}{l}, 715 \\
, 802 \\
, 229\end{array}$ & $\begin{array}{l}, 041 \\
, 086 \\
, 189\end{array}$ & $\begin{array}{l}, 641 \\
, 777 \\
, 010\end{array}$ & $\begin{array}{l}6,215 \\
9,324 \\
4,121\end{array}$ & $\begin{array}{l}, 007 \\
, 000 \\
, 024\end{array}$ \\
\hline
\end{tabular}

a. Dependent Variable: Loyalitas_nasabah

Sumber: Data diolah pada tahun 2021

Berdasarkan tabel 4.6 diketahui bahwa:

1. Hasil uji $\mathrm{t}_{\text {hitung }}$ untuk variabel kualitas pelayanan sebesar $6,215\left(\mathrm{t}_{\text {hitung }}=6,215>\mathrm{t}_{\text {tabel }}=1,670\right)$ dengan signifikansi sebesar 0,000 yang berarti bahwa ada pengaruh kualitas pelayanan terhadap loyalitas nasabah PT Bank BRI Cabang Bandar Lampung.

2. Hasil uji $t_{\text {hitung }}$ untuk variabel pemasaran relasional sebesar $9,324\left(t_{\text {hitung }}=9,324>t_{\text {tabel }}\right.$ $=1,670$ ) dengan signifikansi sebesar 0,000 yang berarti bahwa ada pengaruh pemasaran relasional terhadap loyalitas nasabah PT Bank BRI Cabang Bandar Lampung.

3. Hasil uji $t_{\text {hitung }}$ untuk variabel kepuasan pelanggan sebesar $4,121\left(t_{\text {hitung }}=4,121>t_{\text {tabel }}=1,670\right)$ dengan signifikansi sebesar 0,024 yang berarti bahwa ada pengaruh kepuasan pelanggan terhadap loyalitas nasabah PT Bank BRI Cabang Bandar Lampung.

Berdasarkan hasil uji $\mathrm{t}_{\text {hitung }}$ untuk variabel kualitas pelayanan sebesar 6,215 $\left(\mathrm{t}_{\text {hitung }}=6,215>\mathrm{t}_{\text {tabel }}\right.$ $=1,670$ ) dengan signifikansi sebesar 0,000 yang berarti bahwa ada pengaruh kualitas 
pelayanan terhadap loyalitas nasabah PT Bank BRI Cabang Bandar Lampung. Tjiptono (2011) menyatakan untuk meningkatkan kualitas pelayanan tidaklah semudah membalikan telapak tangan atau menekan saklar lampu. Banyak faktor yang perlu dipertimbangkan. Upaya tersebut berdampak luas, yaitu terhadap budaya organisasi secara keseluruhan. Di antara berbagai faktor yang perlu mendapatkan perhatian adalah mengindentifikasikan determinan utama kualitas jasa, mengelola harapan pelanggan, mengelola bukti (evidence) kualitas jasa, mendidik konsumen tentang jasa, menegmbangkan budaya kualitas, menciptakan automating quality, menindaklanjuti jasa dan mengembangkan sistem informasi kualitas jasa.

Berdasarkan hasil uji $t_{\text {hitung }}$ untuk variabel pemasaran relasional sebesar 9,324 $\left(\mathrm{t}_{\text {hitung }}=9,324>\right.$ $\mathrm{t}_{\text {tabel }}=1,670$ ) dengan signifikansi sebesar 0,000 yang berarti bahwa ada pengaruh pemasaran relasional terhadap loyalitas nasabah PT Bank BRI Cabang Bandar Lampung. Menurut Litle dan Marandi (2010): menyatakan bahwa "Pemasaran relasional adalah suatu alternatif strategi terhadap pendekatan bauran pemasaran tradisional sebagai suatu cara memperoleh keunggulan kompetitif yang berkesinambungan dan cara yang terbaik untuk mempertahankan pelanggan dalam jangka panjang". Bicket dalam Lupiyoadi (2009) menyatakan bahwa "Pemasaran relasional adalah pemasaran database yang menekankan pada aspek pemasaran yang dihubungkan dengan usahausaha database." Burhn dalam Lupiyoadi (2009) menyatakan bahwa "Pemasaran relasional sebagai semua tindakan menganalisis, merencanakan, merealisasikan dan mengendalikan ukuran yang memprakarsai, menyetabilkan, meningkatkan dan mengaktivasi hubungan bisnis dengan stakeholder perusahaan, terutama pelanggan, untuk tujuan saling menciptakan nilai masing-masing ". Pemasaran relasional (relationship marketing) sangat relasional dan relevan untuk di bahas dalam pemasaran jasa, mengejar keterlibatan dan interaksi antara pelanggan dan pemberi jasa. Pendekatan pemasaran yang hanya berorientasi transaksi (transactional marketing) dengan sasaran pnejualan yang tinggi dalam jangka pendek menjadi kurang mendukung pada prektek bisnis jasa. Pemasaran relasional menekankan pada usaha menarik dan mempertahankan pelanggan melalui peningkatan hubungan perusahaan dengan pelanggannya (Lupiyoadi, 2009).

Berdasarkan hasil uji $t_{\text {hitung }}$ untuk variabel kepuasan pelanggan sebesar $4,121\left(t_{\text {hitung }}=4,121>t_{\text {tabel }}\right.$ $=1,670$ ) dengan signifikansi sebesar 0,024 yang berarti bahwa ada pengaruh kepuasan pelanggan terhadap loyalitas nasabah PT Bank BRI Cabang Bandar Lampung. Dalam persaingan perbankan yang semakin ketat, faktor kepuasan pelanggan menjadi perhatian yang serius. Pelayanan dan kepuasan pelanggan merupakan aspek penting dalam rangka bertahan dalam bisnis dan persaingan. Berikut definisi beberapa ahli tentang kepuasan pelanggan menurut Sabran (2010:177) menyatakan bahwa : "Kepuasan adalah perasaan senang atau kecewa seseorang yang muncul setelah membandingkan kinerja (hasil) produk yang dipikirkan terhadap kinerja (atau hasil) yang diharapkan."

Menurut Tjiptono (2008:24) menyatakan bahwa : "Kepuasan adalah sebagai suatu tanggapan emosional pada evaluasi terhadap pengalaman konsumsi suatu produk atau jasa". Menurut Tjiptono (2008:24) menyatakan bahwa: "Kepuasan pelanggan merupakan evaluasi purna beli dimana alternatif yang dipilih sekurang-kurangnya sama atau melampaui harapan pelanggan, sedangkan ketidakpuasan timbul apabila hasil (outcome) tidak memenuhi harapan" Dalam penelitian ini kepuasan pelanggan yang dipergunakan adalah menurut pendapat Parasuraman (2009:117) yang meliputi kinerja yang diharapan konsumen dan harapan konsumen, jika kinerja berada dibawah harapan, pelanggan tidak puas, jika kinerja melebihi harapan, maka pelanggan amat puas atau senang. 


\section{KESIMPULAN}

Berdasarkan hasil penelitian dan pembahasan, maka dapat diambil kesimpulan bahwa

a. Ada pengaruh kualitas pelayanan terhadap loyalitas nasabah PT Bank BRI Cabang Bandar Lampung

b. Ada pengaruh pemasaran relasional terhadap loyalitas nasabah PT Bank BRI Cabang Bandar Lampung

c. Ada pengaruh kepuasan pelanggan terhadap loyalitas nasabah PT Bank BRI Cabang Bandar Lampung

d. Ada pengaruh kualitas pelayanan, pemasaran relasional dan kepuasan pelanggan terhadap loyalitas nasabah PT Bank BRI Cabang Bandar Lampung

\section{DAFTAR PUSTAKA}

Arikunto, 2002, Metodologi Penelitian. Penerbit PT. Rineka Cipta. Jakarta.

Aryani. D dan Rosinta. F. 2010. Pengaruh kualitas Layanan Terhadap Kepuasan Pelanggan Dalam Membentuk Loyalitas Pelanggan. Jurnal Ilmu Administrasi dan Organisasi.Vol.17.No.2.

Assauri, 2008, Manajemen Pemasaran: Dasar, Konsep dan Strategi. Penerbit : Gramedia Pustaka Utama, Jakarta

Chan S, 2008, Building customer loyalty in the digital age through relationship marketing (RM) and the mediation effect of trust", Proceedings of the $5^{\text {th }}$ International Conference on Operations and Quantitative Management, Seoul, South Korea, Korea, pp. 293-302

Chandra dan Danny, 2010, Analisis Kepuasan dan Loyalitas Konsumen Terhadap Tingkat Penjualan di Warung Bu Kris. Jurnal Manajemen \& Kewirausahaan,Vol. 3, No. 2, 85 $-95$

Cornelia. 2008. Analisa Pengaruh Kualitas Layanan Terhadap Loyalitas Pelanggan di Laundry 5 asec Surabaya. Skripsi.

Dinawan, 2010, Analisis faktor-faktor yang mempengaruhi keputusan pembelian (studi kasus pada konsumen Yamaha Mio PT Harpindo Jaya. Semarang). Jurnal Penelitian.

Edvardsson, et al., 2010, The effects of satisfaction and loyality on profits and growth : products versus services”, Total Quality Managemen, Vol. 11 (7) : pp. 917-927.

Gronross, 2008, Service management and Marketing 3. Edisi terjemahan, Penerbit : Gramedia Pustaka Utama, Jakarta

Hastono, 2001, Analisis Data. Jakarta, Penerbit Pustaka Fakultas Kesehatan. Masyarakat-UI.

Hurriyati, 2010, Bauran Pemasaran Jasa dan Loyalitas Konsumen. Alfabeta. Bandung

Kotler. Philip. 2010. Manajemen Pemasaran Jilid 1 (11th ed.). PT. Indeks: Jakarta.

Kurniasih. 2012. Pengaruh harga dan kualitas pelayanan terhadap loyalitas pelanggan melalui variabel kepuasan (Studi Pada Bengkel Ahass 0002-Astra Motor Siliwangi Semarang). Skripsi

Laksana. Fajar. 2008. Manajemen Pemasaran. Edisi Pertama. Yogyakarta: Graha Ilmu.

Lamarto, 2009, Azas-azas Marketing, Edisi Ketiga. Erlangga, Jakarta.

Leliana dan Suryandari, 2006, Price Perception In Customer Shopping Behaviour Jurnal Bisnis Dan Manajemen Volume 4. Nomor 2, p111

Lichenstein et al. 2006, Manajemen Pemasaran Modern, Liberty, Yogyakarta

Mollan, 2007, Manajemen Pemasaran, Edisi Keduabelas, Jilid 1, PT. Indeks

Parasuraman,1988, Servqual: A Multiple-Item Scale for Measuring Consumer Perception of Service Quality. Journal of Retailing, Vol. 64. pp 12-40.

Prabowo, 2002, Pemasaran Jasa, Cetakan I, Edisi I,Andi, Yogyakarta. 
Priyatno 2008, Paham Analisis Statistik Data Dengan SPSS. Yogyakarta : Mediakom.

Sabran, 2010, Pemasaran Bank. Jakarta : Kencana Prenada Media Group

Sistaningrum, 2010, Intisari Pemasaran dan Unsur-Unsur Pemasaran. Edisi Ketiga, Penerbit Sugiyono, 2011, Metode Penelitian Administrasi, Penerbit Alfabeta Bandung.

Sunandar, 2008. Pengaruh persepsi kualitas pelayanan. kualitas produk dan harga terhadap loyalitas pelanggan flexi di Kota Semarang dengan intervening kepuasan pelanggan. Skripsi.

Swastha, 2009, Manajemen Pemasaran dan Pemasaran Jasa. Bandung: Alfabeta

Tjiptono. 2008. Manajemen Jasa. Yogyakarta: Andi Offset.

Wahyudi, 2006, Metodologi Penelitian Ekonomi. FEUI. Jakarta.

www.trivago.com. Hasil Survey Hotel trivago,com, 2015

Yesenia. 2013. Pengaruh Kualitas Layanan dan Produk terhadap Kepuasan serta Loyalitas Pelanggan Kentucky Fried Chicken di Tangerang Selatan. Skripsi. 